\title{
Collective action of 'Others' in Sydney
}

\section{Walter Lalich, University of Technology Sydney}

Collective actions are often undertaken by segments of 'other' ethnic communities to satisfy collectively perceived needs in a place of settlement. Through collective action groups of people of particular ethnic background mobilize resources to develop necessary collective goods. To facilitate their settlement in the new social environment many groups of non-English speaking people background develop their own spiritual and secular places, a communal home in Sydney. They appropriate facilities that meet a certain communal need, like places of worship, social and sporting clubs, schools, childcare and diverse welfare facilities. Ethnic collectives establish communal roots and create a new social and physical landscape with impact beyond local territorial boundaries.

This development is dependent upon the collective will of concerned individuals confronted with external pressures, exclusion, and internal constraints. It is indicated by Said $(1983,15)$ that the individual mind registers and is very much aware of the collective whole, context, or situation in which it finds itself, and reacts as a social actor. Collective acts as modes of confronting the new environment are materialised through the voluntary development of social infrastructure by migrant actors.

The decision to appropriate a necessary place to satisfy an urgently perceived need is made by a particular group following the initiative concerning the particular issue of significance for their immediate group. This initiative and action is often generated from 
several people, or even a single person, at a grass-roots level. On rare occasions only is such a development a product of a hierarchically structured body, either a religious or secular umbrella organisation. It mostly reflects awareness by a group of individuals that they have to and can solve some collectively perceived problem with the intention of enhancing the quality of their lives. Among the major issues of concern are spiritual, recreational, maintenance of language, as well as the childcare or aged care needs of that group of people. From networks and informal meetings, formal organisations develop, following local practice, to pursue the action aiming to establish needed facilities.

This article begins with a brief discourse on key theoretical concepts of collective action and communal places, considered as collective goods, being the outcome of fragmented collective acts. The creation of urban landscape by 'others' is best identified through the visible communal places established by diverse ethnic collectives. Data on demographic and cultural changes in the post-1945 period identify the intensity of settlement constraints and migration-derived demand for collective goods and migrant response.

The arrival of large numbers of settlers from diverse parts of the world into the transferred British socio-cultural outpost of Sydney was a cultural shock for both the settlers and descendants of earlier settlers. The development of ethnic ${ }^{1}$ social infrastructure was an act of resistance (Pile 1997, 3; Melucci 1996, 183) to the sociocultural uniformity and assimilation pressures that many settlers encountered even after the 1970s (Batrouney 2002, 57; Jupp 2002, 22-24; Murphy 2000, 161; Lopez 2000, 46; Hage 1998, 82, 235; Lewins 1978: 38). Many immigrants wanted to continue religious service in their own language, to communicate and socialise in their own language, to play sports they knew, to maintain and transfer culture to the next generation, and to enjoy traditional food and drinks (Powell 1993, 83). For these purposes, ethnic groups had to develop their own communal places. The second half of this article presents information on the outcome of ethnic collective action in Sydney over the second half of the last century: the development of communal places. The article concludes with an

\footnotetext{
${ }^{1}$ Ethnic in the Australian context indicates first or second generation immigrants of non-English speaking background or origin, NESB (Martin 1981). In this essay the term is interchanged with migrant.
} 
observation on the diverse social implications of this endeavour, fragmented by cultural, religious, linguistic, ideological and environmental influences.

\section{Collective action}

Collective motivation and the commitment of migrants to improve their quality of life enables the development of various places that satisfy a certain collectively perceived need in a new social environment: communal places. The purpose of collective action is to advance common or collective interests and solve perceived problems through provision of collective goods that cannot be provided otherwise or efficiently through the channels of the host environment (Hechter, et al 1982, 415; Hannerz 1974, 60; Olson 1965,5). A reference to Durkheim’s $(1964,283)$ notions of 'collective conscience’, as a system of functions determining an equilibrium helps in the comprehension of a collective action. The concept suggests possible collective ends or values that emerge in human interaction during settlement, and that could shape the course of social relations, but also become the core of collective motivations and define the outcome of interaction among members of a collective.

Ethnic collective action is a local response to diverse social and cultural constraints, deprivation, and the inadequacy of mainstream social infrastructure. Observed settlement experiences confirm an observation by Polanyi $(1957,46)$ : that individual economic interests are not always the most important, as many migrants pursue non-economic aims as well, including the maintenance of social ties and the enhancement of collective wellbeing. Immigrants pool resources in prescriptive collective action to achieve outcomes that could not be acquired individually. Collective acts often precede solutions to household problems, as migrants resort to mutual help to solve collectively perceived problems.

A group of people enters into collective arrangements to make decisions about joint investment, resources, location, construction, management, control, maintenance and service delivery. The collective defines goals to be achieved with the intent of 'achieving position in relation to the environment’ (Luhmann 1995, 198). Similarly, Coleman (1990, 
300) argues that social relationships develop among individual actors who attempt to make the best use of available resources over which they have control. It is ascertained that marginalisation and alienation stimulate attachment among co-ethnic migrants, which helps in defining courses of collective action and the mobilization of resources (Hechter et al 1982, 421).

A migrant collective act is made feasible by enhanced social capital during settlement in the new social environment. Social capital, understood as a joint interaction of norms, networks and trust (Putnam 1993, 17; Coleman 1990, 302; Bourdieu 1993, 32) could be considered to be at its highest level at a time of settlement. Social capital as the bonding thread (Portes 1995, 12) facilitates the development of communal infrastructure during settlement in a new social environment. Moreover, social capital is itself enhanced as a result of successful communal endeavour within a developed communal place. Through the defined node in social space, a communal place that bridges social capital (Putnam 2000,23 ) is engendered towards the rest of community, expanding beyond physical boundaries.

Solidarity among co-ethnic migrants intensifies due to common settlement experiences, although many may have arrived with no previous mutual contacts. Solidarity facilitates networks among the people on the basis of the shared language and culture of those who also share the same settlement experience. Immigrant solidarity, networks and enhanced trust are key factors impacting on self-reliance, mutuality and collaboration on tasks deemed to be for a common good. A high level of mutual trust and a common settlement experience encourages individuals to join forces to solve perceived problems.

The development of communal organisations is the outcome of fragmented ethnic collective acts in the new environment. In their study, Gamm and Putnam (2001, 207210) emphasise that the growth of associations in the USA from 1870 to 1920 was due to the effects of industrialisation, urbanization, a structured division between work and leisure time, and network-based immigration. This is reflected in the post-1945 Australian social experience in the development of ethnic organisations and their 
appropriation of communal places. These developments signify the intensity of the migrants' preoccupation with communal well-being and the resultant collective actions. ${ }^{2}$

\section{Collective goods}

A collective good is a product of the action by individuals who choose to accomplish aims collectively rather than individually (Buchanan and Tullock 1965, 13). Communal places developed by ethnic communities are considered to be collective goods because of the nature of supply and consumption patterns. These places, characterised by their intrinsic social significance for a group of people, have a property of quasi public goods (Buchanan 1987, 18-21; Stiglitz 2000, 14). Without their joint efforts, members of many ethnic collectives would have no adequate place to enjoy spiritual life, socialize, transfer culture to the young or care for the elderly.

These privately produced and maintained collective goods have different forms of exclusion of non-members, at least in the first instance. Hechter $(1987,10,36)$ claims that actors form groups 'in order to consume various excludable jointly produced goods goods whose attainment involves the co-operation of at least two individual producers', and that levels of exclusion could vary. The existence of selective incentives (Olson $1965,51)$ limits the consumption of collective goods only to those who contribute because they, as members of a particular group, jointly develop it reflecting their perceived collective needs.

Similar to public goods, collective goods are characterised by the property of nondepletability in consumption. Ethnic communal places are liminal (Zukin 1992, 222) in the sense that they are both communal and private at the same time, but also in that many would evolve from communal to public spaces during their life-span. These communal places are produced independently by various groups of people, collectives consisting of individuals who join their resources for a common good, and the outcome is a product of the individual's private commitment towards a joint purpose. Still, collective goods are to

\footnotetext{
${ }^{2}$ Data was collected among ethnic organisations in Sydney in the period 1999-2001 for the doctoral thesis on Ethnic Community Capital: The development of ethnic social infrastructure in Sydney, submitted by the author at the University of Technology, Sydney in 2003.
} 
some extent competitive, as migrants may choose, for example, among regional or nonregional co-ethnic clubs, or to join the religious organization closer to the home address.

Ethnic collective goods are qualified by communal homogeneity, and a high degree of emotional commitment and compliance as members of a particular collective engage in solving their own needs. There is a range of social and economic influences on the provision of these collective goods. Economic influences relate primarily to demand intensity, economies of scale and cost minimisation. Social influences on decisions to develop some collective goods vary and could be social rewards or penalties, moral and political considerations, ignorance about available alternatives and desire for selfdevelopment through participation (Frank 1997, 624; Hardin 1982, 22, 102-120). Members of a collective make a decision to commit their time, energy and money to a particular development, instead of meeting in their own homes, inadequate public and commercial premises, or the continued renting, leasing or sharing of available facilities on an irregular basis.

To many individuals, participation in a collective act is a cost-minimising act because the gained benefits are expected to be greater than the cost of joining or sharing the cost of producing a collective good (Buchanan and Tullock 1965, 44). The benefits are primarily social, for example, the establishment of a place where people can have continuous social intercourse, worship collectively, maintain culture, play familiar games, take care of elderly, to be at home. The individual contribution of money and time to develop a particular collective good is outweighed by beneficial social outcomes. Collective goods arise out of the joint action to spread the high costs of production of, for example, a place of worship or school (Hechter 1987, 37). For many immigrants, the rationale of collective action is located in minimising the encountered social cost. The welfare impact of such decisions is of major significance to a collective, and it could be stated that the Pareto criterion (Stiglitz 2000, 57) applies in this case, because a group of individuals is better off without being likely to make anyone else worse off.

Ethnic communal places have tangible material and economic values as a capitalised 
asset, but they also embody important intangible symbolic and social values. The visible communal places developed by 'others' through voluntary grass-roots collective acts differ from the other public places, not only in symbols, but also in the mode of production and the established sense of attachment (Relph 1976, 37).

\section{Post-war social dynamics}

The arrival of over three million settlers of non-English speaking background since 1948 impacted on cultural and social life in Australia. ${ }^{3}$ This immigration is characterised by the heterogeneity of its structure and the predominantly urban settlement induced by the needs of housing, construction, industrialisation, that demanded both labour and markets (Collins 1984, 4; Logan, et al 1981, 41-2). The first post-war settlers encountered an Australia with only 1.8 per cent of the population of non-English speaking background (NESB) settlers in 1947, but by 2001 this share increased to 13.5 per cent (Price, ed.1979, A 92-5; ABS 2001).

Migrants gravitate to major coastal cities and in particular to Sydney. The first major change in demographic structure occurred during the 1950-1960 period when 50,000 European refugees settled in Sydney (Burnley 2001, 129; Kunz 1988, 43-5). The share of non-English speakers in Sydney increased from 2.2 per cent out of a million and a half inhabitants in 1947 to 23.4 per cent out of four million in 2001 (ABS 2001). It is estimated that people of non-English speaking background, first and second generation, together comprise over 54 per cent of the Sydney population (Burnley et al 1997, 33).

The post-war intensification of cultural diversity is best identified with data on language use and religious diversity. In Sydney, 734,198 speakers of over 5 years of age daily used one of twenty major (non-English) languages in 1996, while the other languages were spoken by an additional 175,182 inhabitants, or around 27.0 per cent of all inhabitants in 2001 (ABS 2001; EAC 1998).

\footnotetext{
3 Among many other sources analysing major features of the post-war Australian immigration experience are: Martin 1978; Viviani 1984; Coughlan and McNamara (ed.) 1997; Burnley 2000; 2001; Jupp (ed.) 2001, 2002.
} 
Australia is now home to all major world religions. Although there was immigration by Orthodox, Muslim and Buddhist believers as early as the $19^{\text {th }}$ century, they were barely recorded statistically in 1947, due to the entry restrictions. Followers of these and other newly arrived religious denominations now make up around 14 per cent of the total Sydney population. The large-scale arrival of continental Europeans and later of Asian and Latin American settlers greatly increased the number of Roman Catholic believers, increasing pressures on already existing religious and educational systems developed earlier by predominantly Irish Catholic settlers. Nevertheless, some Roman Catholic communities developed their churches, schools and community centres.

The large numbers of migrants of diverse background meant that the additional and differentiated demand for goods and services could not be satisfied by the limitations of the entrenched local culture and a non-responsive welfare state (Jakubowicz 1989, 275; Cox 1975, 182). Moreover, assimilation was the official policy until the late 1960s. Policy makers for years ignored many issues generated by the arrival of large numbers of people and showed no interest in solving diverse settlement problems (CIE 1992, Xv; Jupp 1991,106; Cox 1987, 90). Despite policy changes since the 1970s and an emphasis on multiculturalism, many non-English speaking migrants still do not feel welcome (Hage 1998, 16; Betts 1999, 316).

New settlers brought new forms of culture, social life and recreation, and new social needs, but Australia was not prepared for the effects of its own ambitious immigration program. At the same time, Sydney was not well endowed with public places and welfare services, like childcare, to which access was further limited due to cultural and linguistic differences (Brennan 1998, 144; Thompson 1994, 205; Spearritt 1978, 36, 241).

\section{Ethnic collective action in Sydney}

Very soon after arrival migrants became conscious not only of marginalisation and a disadvantageous social position, but also of their own potential. This facilitated collaboration of particular groups of people in over sixty ethnic groups on tasks of mutual interest, which differed between the groups, even among people of the same ethnic 
background. Many migrants became aware that their particular collective need could be satisfied only through the appropriation of physical objects. It is estimated that at least 450 ethnic organisations established their own communal places in Sydney between 1950 and 2000. Some organisations purchased and adapted abandoned halls, churches (sometimes with the help of the parent organisation) and even squash courts in older suburbs, and consequently around 80 churches, some dating from the $19^{\text {th }}$ century, acquired a new lease of life. However, the majority of organisations appropriated available vacant land in semi-rural suburbs and constructed the necessary premises. These fragmented acts enabled many settlers to acquire a place of action and commitment where their communal needs are met, a place of belonging, with a feeling of 'home' established. Indeed for many it was at one stage also a place of resistance to social and assimilation pressures. Today, these symbolic places embedded in the social and urban landscape of Sydney create the mainframe of everyday cultural diversity.

Migrant collective action materialised in social space adds a new dimension to the understanding of the settlement process and identifies the complexities of collective actions in Sydney. Data on appropriated places, constructed space and human engagement identify the dynamics of collective action, tangible outcomes and social significance. Also, data on human engagement provide insights into financial involvement and participation in activities that enabled this important development. It is difficult to define created social value, as many social costs and benefits are not readily assessed in monetary terms and it is therefore difficult to estimate (Baumol and Blinder 1985, 543), it is thus difficult to fully recognize, comprehend and measure the extent of the impact of ethnic collective action on social texture.

The dynamics of this development reflect changes in immigration patterns and in processes within the ethnic communities that define goals and identify investment capabilities (access to human, material, financial and organizational resources). The arrival of large numbers of migrants of the same origin and cultural background created necessary thresholds. However, as immigration is structured not only by ethnicity, age and gender, but also by regional, cultural, class and ideological differences, it impacts on 
the perception of priorities, patterns and dynamics of development.

The outcome of these fragmented collective actions is materialised in a new, culturally diverse communal space that enables spiritual life, leisure, recreation, education, childcare and aged-care. Ethnic communal space is established through the activities of many culturally diverse groups in response to local problems within the existing social context and settlement constraints. The consequent collective actions proceed, and often overlap, through the appropriation and production of space (Harvey 1989, 220-221). The dynamics of the appropriation of places over five consecutive ten-year periods by 393 respondent organisations is presented in table 1 . They established over four hundred and seventy thousand square metres of functional communal space where 180,000 persons could find a place of their own at any given moment (Lalich 2004).

Table 1. Developed ethnic communal space, by type and periods of development: Sydney, 1950-2000 (estimated persons; developed units)

\begin{tabular}{|c|c|c|c|c|c|c|c|}
\hline Type/ period & $\begin{array}{l}1950- \\
1960 \\
\%\end{array}$ & $\begin{array}{l}1961- \\
1970 \\
\%\end{array}$ & $\begin{array}{l}1971- \\
1980 \\
\%\end{array}$ & $\begin{array}{l}1981- \\
1990 \\
\%\end{array}$ & $\begin{array}{l}1991- \\
2000 \\
\%\end{array}$ & $\begin{array}{l}\text { Capacity- } \\
\text { persons }{ }^{6}\end{array}$ & $\begin{array}{l}\text { All } \\
\text { units } \\
\text { by } \\
\text { type(n) }\end{array}$ \\
\hline Religious $^{1}$ & 11.9 & 21.1 & 18.7 & 24.3 & 24.0 & 120,029 & 208 \\
\hline Clubs $^{2}$ & 17.9 & 26.7 & 15.8 & 30.0 & 9.6 & 49,151 & 94 \\
\hline Education $^{3}$ & 0.4 & 0.6 & 22.3 & 48.5 & 28.2 & 10,792 & 44 \\
\hline Aged care $^{4}$ & 17.5 & 23.4 & 10.0 & 27.6 & 21.5 & 2,270 & 47 \\
\hline Units/period $^{5}$ & 12.2 & 14.5 & 17.0 & 29.8 & 26.5 & & 393 \\
\hline
\end{tabular}

Notes:

1. Includes places in halls, Sunday school classrooms.

2. Includes sports clubs, but not spectators at sporting events.

3. Includes places in childcare and in tertiary institutions (hostel).

4. Beds in aged care; does not includes places in general welfare organizations.

5. Including eleven general welfare places.

6. Indicates capacity places, not the actual users, attendants, volunteers.

Source: Lalich, W.F. 2004, Ethnic Community Capital, unpublished PhD thesis, UTS, Sydney.

This development also depended on exogenous factors, the socio-economic environment, settlement constraints and public (un)awareness about immigrants' welfare. Post-war development can be divided into two periods. During the initial period until the 1970s, which corresponds broadly to the period of pressure to assimilate, there was rarely public 
support for migrant initiatives. After 1980 the development of ethnic schools, childcare, welfare and aged care received more public support, as public awareness of unsatisfactory conditions facing immigrants surfaced. The Henderson Report of 1970 emphasised migrant deprivation. The federal Whitlam Labor government (1972-1975) introduced various policy measures, and from 1974-75 migrant welfare and educational organisations received material help (Jakubowicz, et al 1984, 38-9). The Galbally Commission in 1978 qualified existing social constraints encountered by new settlers as unsatisfactory, recommending major policy changes. It confirmed the role of ethnic organisations as major service providers to migrants. These changes in development patterns are reflected in table 1, although a diversification of the sources of migration has also impacted on development patterns since 1980.

Collected data show that over 56 per cent of the 393 units were developed since 1980, indicating a persistence of felt needs, accumulation of capital, and the arrival of migrants from new sources. The development of schools, childcare centres and aged-care was facilitated in this twenty-year period by public support. In this period around 77 per cent of all school and childcare capacities, together with 49 per cent of all aged care, were developed. Meanwhile, the need for aged-care was large at the beginning of the post-war settlement.

The continuous intensive development of places of worship significantly increased during the last two decades, due to the expanding sources of immigration. Over 48 per cent of all religious capacities were developed since 1980, responding to demand for places of worship by newly arrived Buddhist, Muslim, Hindu and Oriental Christian believers. Many less recently arrived European Christians built new and larger churches, reflecting increased prosperity, and replacing the older unsatisfactory places of worship and community halls. The data in table 1 indicate the importance of the development of social and sports clubs during the first four decades and a rapid decrease in the last decade. This reflects aging of the post-war migrants who developed clubs to meet their own social and recreational needs, generational changes, and changes in the structure of immigrants and in society, in particular in the hospitality industry. 
The intensity of the development of this segment of communal space over the analysed time period indicates changes in development priorities. Differences in the orientation of ethnic communal action due to the settlement encounters, maintenance of transferred cultures and the ageing process are reflected in the outcomes of collective actions. The development reflects transfer and maintenance of culture, language and heritage, considerations of communal wellbeing, but also of the impact of public support on the development of educational and aged care capacities. ${ }^{4}$ The development emphasis changed from the satisfaction of the immediate social and cultural needs of the first generation of migrants, in places of worship and clubs, to the long-term maintenance of transferred cultures, religions and languages, and to the organised care for weaker members of community across generational changes.

Data on development patterns show that:

- European immigrants have built over 90 percent of all leisure capacities reflecting cultural differences, social deprivation and the evolution of Sydney;

- European Orthodox, non-European Christians, Buddhists, Hindus and Muslims had a major role in the development of places of worship;

- non-European settlers developed most facilities after 1980;

- despite a long tradition of an Irish-dominant local Roman Catholic Church, language and culture specific Catholic churches were developed;

- Asian and Pacific islands Christian communities primarily developed churches, and;

- European (Mediterranean) and Muslim immigrants have developed all respondent day schools and the majority of childcare centres.

\section{Social Value}

Ethnic communal places signify collective consciousness, collective action, participation, and the embeddedness of transplanted cultures in a transforming local and transnational social space. Joint group voluntary investment in ethnic communal places is a result of a

\footnotetext{
${ }^{4}$ As the majority of immigrants were initially single males used to different types of entertainment, many new ethnic social and sporting clubs were initiated. Football, in Australian terminology soccer, was revived by post-war migrants. Itwas much more than a recreational and socialisation pastime for young male immigrants, as it provided opportunities for communication with other sectors of the community, the application of organisational and leadership skills, and a path for inclusion in a new society (Mosely, Cashman, O’Hara and Weatherburn, eds 1997; Caldwell 1987). Migrant-organised football clubs were predominant in Sydney Championships in the 1950s and 1960s; rare were the clubs that had local origins. The First Division in 1967 consisted of Pan Hellenic, Hakoah, Prague, Apia, Polonia, Yugal, Croatia, St George-Budapest, Melita Eagles, and Manly, named after a local beach suburb (Korban 1994).
} 
social choice expressing a relevant social preference (Luhmann 1995, 317). Values formulate action commitments, morally justify preferences and reflect on the outcome. A settler's situation is defined by Olson's $(1965,24)$ proposition that what matters most is not how many collective goods will be produced, but rather whether 'any of the collective goods will be provided'. Communal places as the outcome of ethnic collective action generate intrinsic meaning or values unlike any other form of expenditure. They are imbued with the meaning of home to people who left their place of origin and settled in a new environment.

The settlement experience and constraints define the pattern and the outcome of collective action. Cultural systems provide a key input to any action through the interrelation of the different parts that form value and belief systems, and systems of expressive symbols which define a frame of reference for collective action (Parsons and Shils 1962, 24, 53). The outcome reflects the time and place of settlement that could differ even within the same ethnic group. The full value and effects of ethnic collective action could be assessed only through the comprehension of incorporated intangible social values and externality effects. The appropriated ethnic communal places meet communal needs as perceived by a particular group of people, but also form bridges between cultures in a culturally diverse social environment. The expanded field of social interaction underlines the significance of the outcome of ethnic collective actions.

The development of ethnic communal places correlates to social changes that generate organisational changes, new functions and activities, as well as sources of finance. The sustainability of these places is dependent upon generational changes, and a capacity for continuing to satisfy community needs and to generate communal participation. These places developed in a particular locality have a dual spatial logic; they are a communal home for the members of a group who often live in more distant suburbs, but are also at the same time an important node for its immediate neighbourhood, defining it symbolically as well as appropriating the role of a local heritage.

These visible places in the landscape depend on the persistence of collectively perceived 
needs and a capacity for satisfying the needs of a younger generation and even of new consumers coming sometimes from outside their own ethnic group. Some clubs broaden membership basis; places of worship are shared with believers of some other denomination; children in childcare are often of different ethnic background due to spatial mobility; students in ethnic schools are of different ethnic origin, as are the residents in aged care as a consequence of public financing of aged-care institutions. This indicates the transforming nature of ethnic communal space. Some communal places would inevitably change their role as did many former churches and other public places after having been appropriated by their present users.

The changing nature of a communal place is illustrated by a brief insight into the changes in the Marconi Club, a key sporting and social institution in western Sydney, developed by Italian migrants since 1958. It was a corollary of the need for a public place for the numerous Italian gardeners to gather, socialise, play bocce or football, eat their own food and enjoy wine.

\section{Club Marconi}

Italian settlers arrived in Western Sydney in large numbers after 1950. Powell (1993) describes how Italian immigrants had no place of their own in which they could socialise, have a glass of wine, play bocce or football. Two Italian brothers offered eight acres of land to the community at price of $£ 3,500$, but on delayed repayment terms. The first 100 members, including some Anglo neighbours, raised $£ 5,000$ to start the club, constructing the first building in 1958. A further addition, the Christina lounge, was built in 1962. Following the purchase of additional blocks of land, diverse social and recreation premises were also developed to meet the growing needs of its continuously growing membership. Among its 23,000 members less than half were born in Italy; some were descendants of Italian migrants, but many were born elsewhere, in Europe and Latin America. The later developments included a football stadium for 12,000 spectators, tennis grounds, a multifunctional indoor Boccedromo, childcare, and parking for 1,800 cars. While the club mainly supports traditional Italian recreational activities, it also supports netball and was one of the first clubs to establish female membership. Having grown from a small Italian communal association to a professionally managed institution, Marconi is now a meeting place for many local associations and multiple links with the rest of community and overseas. It is a very visible major node on the urban landscape and a unique cultural space collectively developed to meet the recreational needs of the Italian migrants in the area. 


\section{Participation}

To develop their own communal places migrants rely primarily on their own resources. Their actions enhance collective empowerment and community satisfaction, best emphasised by a motto in the local Assyrian periodical 'let us build it together' (i.e, the Nineveh Club) (Kinarah 1980, 4). This grass-roots development is characterized by significant voluntary involvement of people at diverse stages of the organisational life and at diverse hierarchical levels, often at the expense of family time, earning potential, household consumption and savings. People respond voluntarily with an intensity corresponding to the perceived urgency of settlement situation and felt needs. It is a joint group effort where there are few if any 'free riders' (Coleman 1990, 273). Diverse modes of participation in ethnic communal organisations are shown in table 2.

Table 2. Ethnic communal places, community participation in respondent organisations: Sydney, 2000 (Estimate persons)

\begin{tabular}{|c|c|c|c|c|c|c|}
\hline Institutions & \multirow{2}{*}{$\begin{array}{l}\text { Units } \\
\text { (n) }\end{array}$} & \multirow[t]{2}{*}{ Consumers $^{5}$} & \multicolumn{3}{|c|}{ Volunteers participating $^{6}(\%)$} & \multirow{2}{*}{$\begin{array}{l}\text { Employ } \\
\text {-ees }^{7}\end{array}$} \\
\hline & & & $\begin{array}{l}\text { at } \\
\text { committees }\end{array}$ & $\begin{array}{l}\text { other } \\
\text { activities }\end{array}$ & Total & \\
\hline Religious $^{1}$ & 208 & 191,983 & 20.0 & 80.0 & 11,202 & 595 \\
\hline Leisure $^{2}$ & 94 & 117,412 & 33.5 & 66.5 & 3,436 & 1,196 \\
\hline Education $^{3}$ & 44 & 9,820 & 35.2 & 64.8 & 540 & 1,208 \\
\hline Welfare $^{4}$ & 47 & 2,197 & 22.6 & 77.4 & 1,973 & 1,832 \\
\hline Total & 393 & 321,412 & 23.4 & 76.6 & 17,151 & 4,831 \\
\hline \multicolumn{7}{|c|}{ Notes: } \\
\hline $\begin{array}{ll}\text { 1. } & \text { Inclu } \\
\text { 2. } & \text { Does } \\
\text { 3. } & \text { Inclu } \\
\text { 4. } & \text { Inclu } \\
\text { 5. } & \text { Repo } \\
\text { 6. } & \text { Trust } \\
& \text { estim } \\
\text { 7. } & \text { All e }\end{array}$ & $\begin{array}{l}\text { halls, S } \\
\text { t include } \\
\text { childca } \\
\text { eleven } \\
\text { d regular } \\
\text { bard, cor } \\
\text { of pote } \\
\text { loyees ( }\end{array}$ & $\begin{array}{l}\text { Inday school clas } \\
\text { sports grounds. } \\
\text { e and tertiary ins } \\
\text { eneral welfare o } \\
\text { users, irrespecti } \\
\text { imittee members } \\
\text { tial volunteers th } \\
\text { anagers; full an }\end{array}$ & $\begin{array}{l}\text { rooms. } \\
\text { itutions. } \\
\text { ganizations. } \\
\text { of the form. } \\
\text { regular volunt } \\
\text { t increases sub } \\
\text { part time worl }\end{array}$ & $\begin{array}{l}\text { eers in other act } \\
\text { stantially in the } \\
\text { ers). }\end{array}$ & $\begin{array}{l}\text { ivities. Cons } \\
\text { case of neec }\end{array}$ & lered as a lowe \\
\hline
\end{tabular}

Source: Lalich, W.F. 2004, Ethnic Community Capital, Unpublished Ph D Thesis, UTS, Sydney.

People contribute their physical and creative labour, and material resources to the development of communal places. For many this is an opportunity to volunteer time and finances, to express their organisational and business acumen, as well as leadership 
skills. ${ }^{5}$ Participation by volunteers is of paramount importance at all stages of the organisational life cycle and is expressed through work and consumption, financial and other material contributions. Data in table 2 show that among over 17,000 regular volunteers, nearly a quarter are active in committees creating a new hierarchical system with a leadership structure. Some remain in these key functions for years, often due to their skills, ability, time, charisma and resources donated towards development and organisational maintenance. For many small organisations direct member participation is their mode of existence, of their sustainability. Communal centres also create many new employment opportunities as well; over 4,800 persons are employed, including people from outside the serviced ethnic community. Among the employed are priests, teachers school principals, managers of aged-care facilities and some social clubs, creating a new social hierarchy. Volunteers and employees help to organise life and activities in 393 communal places where over 320,000 persons satisfy their spiritual, social, cultural and welfare needs.

Many communal places are erected by voluntary labour, minimising material cost, but the extent of participation is difficult to assess because of insufficient records and difficulties in estimating the value of volunteer input in society. However, estimates of voluntary participation in Australia provide an insight into the significance of voluntary participation in ethnic communal organisations. The reported lower estimate of national weekly participation of approximately 2.3 hours per volunteer (Ironmonger 2000, 61; Lyons 1994, 37), if applied to an estimated 17,150 current volunteers in ethnic communal places, indicates that they alone contributed at least 2.1 million hours in 2000. However, any attempt to estimate the social value of migrant voluntary participation, applied skills and emotional engagement would have to take into account that most of this work was done after work, during weekends and holidays.

The respondent ethnic collectives generated investment in communal space and created property with an estimated value of around two billion Australian dollars. This estimate

${ }^{5}$ Some examples of the registered voluntary work: during construction of: the Russian Orthodox Archangel Michael Church 2,670 hours were donated between 1959 and 1965 (1984); the Macedonian Orthodox church, St Petka, benefited from at least 597 voluntary work days, in addition to contracted work, during four months of construction in 1977 (Cirevski 1999). 
only partly reflects the full extent of material involvement by many thousands of migrants. Public authorities (state and federal) supported the development of schools and childcare with 17 per cent, and aged care places with 31 per cent of investment (Lalich 2004) through direct and indirect assistance, including capital investment and the financing of part of the current expenditure. The estimated public financial involvement, together with a reportedly very limited overseas public and private funding amounted to around 13 per cent of the total recorded investment. At the same time, many organisations had difficulties in securing bank loans, encountered unfriendly neighbours and inflexible local councils, dissipating energy and resources on court litigations (Dunn 2001).

\section{New social interactions}

Established functions and generated activities at or from communal places identify diversity and the intensity of the impact of ethnic collective action on development as a new field of social interaction. Many organisations have developed far beyond their initial function as they respond to changes in society and to perceptions of communal needs, enabling diverse bonding and bridging effects with the rest of the community and world.

The diversity of established functions facilitates the realisation of more than 5,500 diverse activities that enable satisfaction of the social needs of over 180,000 persons in Sydney (Lalich 2004). These beneficial effects provide the best description of the achieved social values and social capital. The established functions and generated activities satisfy the immediate social needs for spiritual life, recreation, maintenance of culture and care, but also enable various forms of cultural exchange, including school visits, participation in local festivities and sporting competitions, and collecting aid. The best-known instances of the impact on social life in Sydney are in the emancipation of non-traditional religious denominations, spreading private education among new culturally defined consumers, the introduction of new sports, creating a jovial atmosphere at festivities, public celebration of various Asian New Years and other festive events. 
Ethnic collective action does not occur in isolation as it is created in a socio-spatial environment defined by different levels of conduciveness. Any activity, production or consumption of goods and services or subsequent linkages, could generate unpriced byproducts or externalities that could affect other actors (Harvey 1973, 57). It is argued by Chinitz and Tiebout (1965, 255-9) that there are problems in determining the share of costs between communities. There apparently is no ideal situation and any decision to develop a collective good could have an impact on different social structures. Beneficial externalities evolve through compensation for public inefficiencies (Baumol and Blinder 1985, 542) in the provision of necessary services to immigrants because otherwise there would be additional pressure on limited mainstream services and facilities (Cutts 1992, 37; Murphy, et al 1990, iii, xii).

Ethnic communal places are key elements of ethnic institutional completeness (Breton 1964, 194) and of the urban built environment. They are permanent nodes on the landscape with a significance that often extends beyond ethnic boundaries through impact on the local social environment. In many instances non-co-ethnic members participate in activities and many services are provided to the benefit of the broader community, indicating the gradual conversion of some communal places into public places. Furthermore, Zukin $(1995,115)$ indicates that cultural spaces in their many guises also enhance the economic value of commercial and residential property. Despite the contrary arguments, the positive ‘spatial field of effects’ (Harvey 1973, 60) of newly developed ethnic communal places is here emphasised.

Unlike most commercial places, ethnic communal places are dispersed throughout the metropolitan area. Although they have cultural boundaries, these places have no fixed space limits, as to many consumers dispersed throughout the metropolitan area the large distances are not an obstacle for participation in communal life. Their location mostly depends on the available accessible space, and many are located close to railways stations, and some form clusters. In most cases ethnic communal clusters are multifunctional and culturally diverse, precluding the intensity of the impact of the much denser commercial development. Such concentrations are key places of urban attraction, 
as well as places of tourist consumption.

The revival of football (or soccer), introduction of bocce (Mediterranean hard court bowling), dragon boat races and the popularisation of lion dancing are among other major influences generated from these places. Football and other sports helped many migrants to survive. Participation in sports was a mode of identity creation, group empowerment, social exchange, inter-cultural contacts and the establishment of links with the mainstream society (Margo 2000, 108; Mosely 1997, 42; Cashman 1995, 163). Similarly, new religious and school buildings increased awareness of the local community about religious, cultural and linguistic differences, opened new options for spiritual practices and increased a degree of tolerance unknown in the time of White Australia and assimilation policies. These places are the key nodes of the Australian multicultural experience.

Although the development of these places reflects local settlement needs, their externality effects extend beyond the local social and physical boundaries, as ethnic communal places create and share the transnational social space (Smith, Guarnizo 1998). Hence, it is possible to paraphrase a comment by Dilnot $(1997,7)$ that the clearest externality is that we all benefit from a more satisfied community in terms of 'greater productivity and from the more civilized and humane society that we expect to flow' from a more satisfied community.

\section{Conclusion}

Ethnic collective actions enable the transfer of cultures, customs, and lifestyle, thereby contributing to social changes and the new urban landscape. The collective actions undertaken were the only way to satisfy perceived community needs and to create a 'normal' life (Jamrozik 1983, 142). This creative collective endeavour-based on selfreliance, personal sacrifices and the voluntary contribution of time and resources-is compensated for by the achieved utility and social values, empowerment and inclusion in the new environment. This migration-generated communal investment differs from other forms of either public or private investment in social infrastructure. 
Many elements of Sydney's urban resources are the outcome of materialised collective actions undertaken autonomously by diverse migrants. These reflect differences in the development patterns and life cycles of organisations. Migrants have established essential organisational support networks, key elements of (ethnic) institutional completeness in a continuously changing society, complementing other social institutions. Although various impediments were encountered during development, the provision of public support facilitated the development of educational and aged-care facilities and secured the continuity of these services.

Ethnic collective action enriched the social, cultural, religious and sporting life of many old and new suburbs, creating signifiers of cultural diversity in Sydney. This development is much more important than simply an immigrant intervention in space. The significance of ethnic communal places transcends their immediate communal intent and suburban limits, opening up possibilities for broadly based inter-cultural practices. In the process, collective action of this kind enables many migrants to discard modes of resistance and instead seek inclusion in transformative local and transnational social spaces.

\section{Reference list}

Australian Bureau of Statistics 2001, 2001 Census Statistics, Canberra.

Baumol, W. J. \& Blinder, A. S. 1985, Economics: Principles and Policy, 3rd ed., Harcourt Brace Jovanovich, New York.

Betts, K. 1999, The Great Divide, Duffy \& Snellgrove, Sydney.

Bourdieu, P. 1993, Sociology in Question, trans. R. Nice, Sage Publications, London.

Brennan, D. 1998, The Politics of Australian Child Care: Philanthropy to Feminism and Beyond, Rev. ed., Cambridge University Press, Melbourne.

Breton, R. 1964, 'Institutional completeness of ethnic communities and the personal relations of immigrants', American Journal of Sociology, 70.2, 193-205.

Buchanan, J. 1987, Public Finance in Democratic Process: Fiscal Institutions and Individual Choice, University of North Caroline Press, Chapel Hill.

Buchanan, J. M. \& Tullock, G. 1965, The Calculus of Consent: Logical Foundations of Constitutional Democracy, Ann Arbor Paperbacks, Ann Arbor.

Burnley, I. H. 2001, The Impact of Immigration on Australia: A Demographic Approach, Oxford University Press, Melbourne. 
Burnley, I. H., Murphy, P. \& Fagan, R. 1997, Immigration and Australian Cities, The Federation Press, Sydney.

Cashman, R. 1995, Paradise of Sport: The Rise of Organised Sport in Australia, Oxford University Press, Melbourne.

Centre for International Economics (CIE) 1992, Immigration and the Commonwealth Budget, Bureau of Immigration Research/ AGPS, Canberra.

Chinitz, B. \& Tiebout, C. M. 1964, 'The role of cost-benefit analysis in the public sector of metropolitan areas' in Urban Public Expenditures, ed. J. Margolis, Resource for the Future/John Hopkins Press, Baltimore.

Cirevski, K. 1999, Makedoncite vo Novata Tatkovina, No Pub., Sydney.

Coleman, J. S. 1990, Foundations of Social Theory, The Belknap Press of Harvard University Press, Cambridge, Mass.

Collins, J. 1984, 'Immigration and class' in Ethnicity, Class and Gender in Australia, (eds) G. Bottomley and M. de Lepervanche, Allen \& Unwin, Sydney.

Coughlan, J. E. \& McNamara, D. J. (eds) 1997, Asians in Australia: Patterns of Migration and Settlement, Macmillan, Melbourne.

Cox, D. 1975, 'The role of ethnic groups in migrant welfare' in Welfare of Migrants, Commission of Inquiry into Poverty/ AGPS, Canberra. 1987, Migration and Welfare: An Australian Perspective, Prentice Hall, Sydney. Cutts, L. 1992, Immigration and Local Government Budgets, BIR/ AGPS, Canberra.

Dilnot, A. 1997, 'Crisis in welfare' in Welfare and Values: Challenging the Culture of Unconcern, eds P. Askonas and S. F. Frowen, MacMillan, London.

Dunn, K. 2001, 'Representations of Islam in the politics of mosque development in Sydney’, Tijdschrift voor Economische en Soziale Geografie, 92.3, 291-308.

Durkheim, E. 1964, The Division of Labor in Society. trans. G. Simpson, The Free Press, New York.

Ethnic Affairs Commission (EAC) 1998, The People of New South Wales: Statistics from the 1996 Census, New South Wales Government, Sydney.

Frank, R.H. 1997, Microeconomics and Behaviour, 3rd ed, Irwin/McGraw Hill, Boston.

Galbally, F. 1978, Migrant Services and Programs: Report of the Review of Post-Arrival Programs and Services for Migrants, AGPS, Canberra.

Gamm, G. \& Putnam, R. D. 2001, 'The growth of voluntary associations in America, 1840-1940' in Patterns of Social Capital: Stability and Change in Historical

Perspective, ed. R. I. Rotberg, Cambridge University Press, Cambridge.

Hage, G. 1998, White Nation: Fantasies of White Supremacy in a Multicultural Society, Pluto Press, Sydney.

Hannerz, U. 1974, 'Ethnicity and opportunity in urban America' in Urban Ethnicity, ed A. Cohen, Tavistock, London.

Hardin, R. 1982, Collective Action, The John Hopkins Press, Baltimore.

Harvey, D.1973, Social Justice and the City, Edward Arnold, London. 1989, The Urban Experience, Basil Blackwell, Oxford.

Hechter, M. 1987, Principles of Group Solidarity, University of California Press, Berkeley.

Hechter, M., Friedman, D. \& Appelbaum, M. 1982, 'A theory of ethnic collective action', International Migration Review, 16.2, 412-434.

Henderson, R. F., Harcourt, A. \& Harper, R.J.A .1970, People in Poverty: A Melbourne 
Survey, Chesire, Melbourne.

Ironmonger, D. 2000, 'Measuring volunteering in economic terms' in Volunteers and Volunteering, eds J. Warburton and M. Oppenheimer, The Federation Press, Sydney.

Jamrozik, A. 1983, The New Polish Immigrants: A Quest for Normal Life, Polish Task Force / EAC NSW, Sydney.

Jakubowicz, A. 1989, “"Normalising aliens”: The Australian welfare state and the control of immigrant settlement' in Australian Welfare-Historical Sociology, ed. R. Kennedy, The MacMillan, Melbourne.

Jakubowicz, A., Morrisey, M. \& Palser, J.M. 1984, Ethnicity, Class and Social Policy in Australia, UNSW Social Welfare Research Unit, Sydney.

Jupp, J.1991, Immigration, Australian Retrospectives, Sydney University Press, Sydney. (ed.) 2001, The Australian People: An Encyclopedia of the Nation, Its People and their Origins, Cambridge University Press, Melbourne.

— 2002, From White Australia to Woomera; The Story of Australian Immigration, Cambridge University Press, Melbourne.

Kinarah Special Commemorative Issue 1980, Sydney.

Korban, R. 1994, 40 Lat Klubu Sportowego-Polonia, Sydney.

Kunz, E. F. 1988, Displaced Persons; Calwell's New Australians, The ANU Press, Sydney.

Lalich, W. F. 2004, Ethnic Community Capital: The Development of Ethnic Social Infrastructure in Sydney, Unpublished Ph D Thesis, University of Technology, Sydney.

Lewins, F. W. 1978, The Myth of the Universal Church: Catholic Migrants in Australia, ANU Faculty of Arts, Canberra.

Logan, M. I., Whitelow, J. S. \& McKay, J. 1981, Urbanization: the Australian Experience, Shillington House Melbourne.

Lopez, M. 2000, The Origins of Multiculturalism in Australian Politics 1945-1975, Melbourne University Press, Melbourne.

Luchmann, N. 1995, Social Systems, trans. J. Bednarz, Jr. and D. Baecker, Stanford University Press, Stanford.

Lyons, M. 1994, Australia's Nonprofit Sector, Working Paper Series, No.13, 2nd ed., UTS/CACOM, Sydney.

Margo, J. 2000, Frank Lowy: Pushing the limits, HarperCollins, Sydney.

Martin, J. 1978, The Migrant Presence, Allen \& Unwin, Sydney. 1981, 'Ethnic pluralism and identity' in The Ethnic Dimension, (ed) S. Encel, Allen \& Unwin, Sydney.

Melucci, A. 1996, Challenging Codes, Cambridge University Press, Cambridge.

Mosely, P. A. 1997, 'The Italian Community' in Sporting Immigrants, (eds) P. A. Mosely, R. Cashman, J. O’Hara and H. Weatherburn, Walla Walla Press, Sydney.

Mosely, P. A., Cashman, R., O’Hara, J. \& Weatherburn, H. (eds) 1997, Sporting Immigrants: Sport and Ethnicity in Australia. Walla Walla Press, Sydney.

Murphy, P. A. et al 1990, Impact of Immigration on Urban Infrastructure, AGPS/BIR, Canberra.

Olson, M. 1965, The Logic of Collective Action, Harvard University Press, Cambridge, Mass. 
Parsons, T. \& Shils, E. (eds) 1962, Towards a General Theory of Action: Theoretical Foundations for Social Sciences, Harper and Row, New York.

Pile, S. 1997, 'Opposition, political identities and spaces of resistance' in Geographies of Resistance, eds S. Pile.and M. Keith, Routledge, London.

Polanyi, K. 1957, The Great Transformation, Beacon Press, Boston.

Portes, A. (ed.) 1995, The Economic Sociology of Immigration: Essays on Networks, Ethnicity, and Entrepreneurship, Russell Sage Foundation, New York.

Powell, D. 1993, Out West: Perceptions of Sydney’s Western Suburbs, Allen \& Unwin, Sydney.

Price, C. (ed.) 1979, Australian Immigration: A Bibliography and Digest, No.4, The ANU, Department of Demography, Canberra.

Putnam, R. D. 1993, Making Democracy Work: Civic Traditions in Modern Italy, Princeton University Press, Princeton, N.J.

2000, Bowling Alone: The Collapse and Revival of American Community, Simon \& Schuster, New York.

Relph, E. 1976, Place and Placelessness, Pion Ltd, London.

Russian Orthodox Church Archangel Michael 1984, 25th Anniversary, Blacktown.

Said, E. W. 1983, The World, the Text, and the Critic, Faber and Faber, London.

Smith, M.P. \& Guarnizo, L. E. (eds) 1998, Transnationalism From Below, Transaction Publications, New Brunswick, N.J.

Spearritt, P. 1978, Sydney Since the Twenties. Hale and Iremonger, Sydney.

Stiglitz, J. E. 2000, Economics of the Public Sector, W. W. Norton \& Company, New York.

Thompson, E. 1994, Fair Enough: Egalitarianism in Australia, UNSW Press, Sydney.

Viviani, N. 1984, The Long Journey: Vietnamese Migration and Settlement in Australia, Melbourne University Press, Melbourne.

Zukin, S.1992, 'Postmodern urban landscape: mapping culture and power' in Modernity and Identity, eds S. Lash and J. Friedman, Blackwell, Oxford. 1995, The Cultures of Cities, Blackwell, Oxford. 